\title{
Human Resources Management Planning for Increasing Precast Productivity Based on PMBOK at XYZ Company
}

\author{
Novika Candra Fertilia ${ }^{a^{*}}$, Raden Yudityo Afri Adji ${ }^{b}$ \\ ${ }^{a}$ Faculty of Engineering, University Mercu Buana Jakarta, Indonesia \\ ${ }^{b}$ Faculty of Engineering, University Mercu Buana Jakarta, Indonesia
}

\begin{abstract}
In the era of globalization, it will demand every company to produce good quality products and also quickly in the completion of the product. XYZ Company is a company engaged in manufacturing. The company produces PCI Girder, Spunpile, U-ditch, and Barrier. But production activities there is a mismatch between the plans and the realization that has been made by the company, especially on spunpile products. The purpose of this study is to find out occurrences that affect human resource management planning and to find out how to manage these occurrences. For the method used, the authors used the method of interviewing, observing and distributing questionnaires. The analysis used is the validity test, reliability test, frequency index, severity index, and importance index. The results of this study are that XYZ company has 4 variables that are most influential in human resource management planning.
\end{abstract}

Keywords: Productivity, Spunpile, Human Resource Management

\section{Introduction}

In the current era of globalization, it will demand every company to produce quality products and also quickly in the completion of the desired product. This requires every worker or employee in the production department to continue working in accordance with the expected productivity in order to achieve the expected production capacity. Productivity is as a comparison between output and input (Taliziduhu, 2012 in the research journal Indah Prasetiya Rini, 2017). While the opinion of other experts says that productivity is a comparison between the results achieved with the participation of labor per unit time (Simanjuntak, 2005 in the research journal Mega Cattleya, et al, 2017).

In order for the company to achieve these goals, the obstacles faced by management are not only the problems of raw materials, equipment or other production machines, but also related to problems surrounding workers or employees (Human Resources) who manage the factors of production (Silfa Rino, 2015). Human resources can be interpreted as the science and art of regulating the relationship and role of the workforce to be effective and efficient in helping the realization of corporate, employee and community goals (Hasibuan, 2002 in the research journal Indah Prasetiya Rini, 2017).

In this case, the company must have a human resource management plan so that the company can achieve its stated goals. According to PMBOK Sixth Edition, 2017, resource management planning is a process that explains how to estimate, execute, and organize a team in a project or a company.

XYZ Company is a company engaged in manufacturing. The company, is a producer of PCI Girder, Spunpile, Udicth, and Barrier for the needs of construction projects such as buildings, road and bridge buildings and other civil buildings. But in its production activities there is a mismatch between the plans and the realization that has been made by the company, especially on spunpile products.

\footnotetext{
* Corresponding author.

E-mail address: novikacandraf@mercubuana.ac.id (Novika Candra Fertilia)
} 
The productivity mismatch is allegedly caused by the existing human resources at XYZ company. The allegations are based on the writer's observation and interview of employees who work in the spunpile workshop as well as from the Head of the Human Resources Section and the Head of the Prodlat Section (Production \& Equipment). So the authors are interested in conducting research on the company and take the title "Human Resources Management Planning for Increasing Precast Productivity Based on PMBOK at XYZ Company". The purpose of this study are: 1) Knowing the events that affect the planning of human resource management to increase precast productivity in XYZ company; 2) Knowing how to manage events that affect the planning of human resource management to increase precast productivity in the XYZ company. The method used in this study is observation, interviews and the distribution of questionnaires to experts and respondents.

\section{Methodology}

In this questionnaire there are criteria for respondents as follows :

1. Staff, operators, supervisors of the XYZ Company.

2. $\quad$ Minimum education Associate Degree (Diploma III).

3. Minimum 5 years work experience

\subsection{Measuring Scale}

Measuring scale is an instrument or tool that requires researchers to assign subjects to categories by assigning numbers or numbers to these categories (Tampubolon, 2018). Scale criteria used by the author in assessing the potential frequency and impact of risk on time in the questionnaire in this study using a Likert Scale.

Table 1. Frequency Measurement Scale (in Indonesia)

\begin{tabular}{lll}
\hline No. & Scale & Score \\
\hline 1 & Sangat Tidak Berpengaruh & 1 \\
2 & Tidak Berpengaruh & 2 \\
3 & Netral & 3 \\
4 & Berpengaruh & 4 \\
5 & Sangat Berpengaruh & 5 \\
\hline
\end{tabular}

(Source : By Author, 2019)

Table 2. Impact Measurement Scale (in Indonesia)

\begin{tabular}{lll}
\hline No. & Scale & Score \\
\hline 1 & Sangat Kecil & 1 \\
2 & Kecil & 2 \\
3 & Sedang & 3 \\
4 & Besar & 4 \\
5 & Sangat Besar & 5 \\
\hline
\end{tabular}

(Source : By Author, 2019)

Table 3. Rating Scale (in Indonesia)

\begin{tabular}{lll}
\hline No. & Scale & Score \\
\hline 1 & Sangat Berpengaruh & 1 \\
2 & Berpengaruh & 2 \\
3 & Cukup Berpengaruh & 3 \\
\hline
\end{tabular}




\begin{tabular}{lll}
\hline No. & Scale & Score \\
\hline 4 & Kecil Berpengaruh & 4 \\
5 & Sangat Kecil Berpengaruh & 5 \\
\hline
\end{tabular}

(Source : By Author, 2019)

\subsection{Reliability Test}

The reliability test aims to determine the level of reliability of data generated by an instrument to ensure the consistency of research instruments in the same concept. Reliability analysis that is commonly used is Cronbach Alpha (C-alpha) analysis. This study conducted a reliability test using the Statistical Package for Social Sciences (SPSS 25.0 for Windows) software program.

Alpha Cronbach Formula :

$$
\mathrm{r}=\frac{k}{k-1} x\left[1-\frac{\sum \sigma_{b}^{2}}{\sigma_{1}^{2}}\right]
$$

Explanation :

$$
\begin{array}{ll}
\mathrm{r} & =\text { Instrument Reliability Value } \\
\mathrm{k} & =\text { Question } \\
\sigma_{b}^{2} & =\text { Item Variant } \\
\sigma_{1}^{2} & =\text { Total Variant }
\end{array}
$$

The formula for item variance and total variance :

$$
\begin{gathered}
\sigma_{1}^{2}=\frac{\sum \mathrm{xt}^{2}}{\mathrm{n}}-\frac{\left(\sum \mathrm{xt}^{2}\right)^{2}}{\mathrm{n}^{2}} \\
\sigma_{b}^{2}=\frac{\mathrm{Jki}}{\mathrm{n}}-\frac{\mathrm{Jkn}}{\mathrm{n}^{2}}
\end{gathered}
$$

Explanation :

$\sum \mathrm{Xt}^{2} \quad=$ The quadrate of the total number of respondent answers

$\sum \mathrm{Xt}=$ Respondent Answer Total

$J k i \quad=$ The sum of the quadrate of all items

Jks $=$ Number of subjects quadrate

$n \quad=$ Respondents

\subsection{Frequency Index Analysis (FI)}

Calculation of Frequency Index (FI) uses the formula :

Frequency Index (FI) $\%=\sum_{i=1}^{5}\left[a \cdot\left(\frac{n}{N}\right)\right] \cdot \frac{100}{5}$

Explanation :

$i=$ Response Category Index (1,2,3,4 dan 5)

$a=$ The value associated with the I-response $(1,2,3,4$ and $5 \ldots)$

$n$ = Number of Respondent

$N=$ Respondents 


\subsection{Analisis Severity Index (SI)}

Calculation of Severity Index (SI) uses the formula :

Severity Index $(\mathrm{SI}) \%=\sum_{i=1}^{5}\left[a \cdot\left(\frac{n}{N}\right)\right] \cdot \frac{100}{5}$

Explanation :

$i \quad=$ Response Category Index (1,2,3,4 dan 5)

$a \quad=$ The value associated with the I-response $(1,2,3,4$ and $5 \ldots)$

$n \quad=$ Number of Respondent

$N \quad=$ Respondents

\subsection{Analysis Importance Index (II)}

Calculation of importance index (II) analysis can be done after the values obtained from the frequency index (FI) and severity index (SI). This calculation is used to show the importance index of the multiplication between frequency and impact.

Importance Index (II) $\%=\left(\frac{\mathrm{FI} . \mathrm{SI}}{100}\right)$

Explanation :

FI = Frequency Index

$\mathrm{SI}=$ Severity Index

\section{Result and Analysis}

This stage I questionnaire was given to experts who were experienced in the field of production and human resource management. The questionnaire in phase I aims to find out and ask for expert opinion about whether or not the variables that have been prepared by the author. Experts who will be questioned as many as 3 people with criteria, namely, a minimum education of Bachelor Degree, a minimum of 20 years work experience for Bachelor Degree and 10 years for Master Degree in the field of production and human resource management.

Then after validating the Phase I experts, the Phase II questionnaire is carried out to see the level of respondents understanding of the variables that have been compiled by the author through the screening stage by the experts through the Phase I questionnaire. At this stage sampling respondents are asked for input, are the variables in question too difficult to understand, so it needs to be simplified. Respondents will be sampled as many as 10 people, with the criteria that is, a minimum of Associate Degree education, a position held by a minimum supervisor, minimum 5 years experience in the field of production and human resources.

Phase III questionnaire is carried out using a questionnaire that has been reprocessed by the author if in the questionnaire stage I and II there are improvements. Phase III questionnaire data collection is carried out using a questionnaire aimed at workers in the spunpile production section to identify variables that influence the planning of human resource management in XYZ companies. Respondents who will be sampled as many as 44 people, with the criteria that is, a minimum of Associate Degree education, a position held by a minimum supervisor, minimum 5 years experience in the field of production and human resources.

After the questionnaire results are obtained in stage III, the validity and reliability tests are then carried out with the following details: 
Table 4. Validity Test Result

\begin{tabular}{|c|c|c|c|c|c|}
\hline Variable & $\begin{array}{l}\text { Scale Mean if Item } \\
\text { Deleted }\end{array}$ & $\begin{array}{l}\text { Scale Variance if Item } \\
\text { Deleted }\end{array}$ & $\begin{array}{l}\text { Corrected Item- } \\
\text { Total Correlation }\end{array}$ & $\begin{array}{l}\text { Cronbach's Alpha if } \\
\text { Item Deleted }\end{array}$ & Hasil \\
\hline $\mathrm{X} 1$ & 98,16 & 227,904 & 0,526 & 0,851 & Valid \\
\hline $\mathrm{X} 2$ & 98,25 & 230,657 & 0,425 & 0,854 & Valid \\
\hline $\mathrm{X} 3$ & 98,14 & 219,655 & 0,698 & 0,846 & Valid \\
\hline $\mathrm{X} 4$ & 98,09 & 244,503 & 0,069 & 0,863 & Not Valid \\
\hline $\mathrm{X} 5$ & 97,2 & 242,585 & 0,365 & 0,857 & Valid \\
\hline $\mathrm{X} 6$ & 98,18 & 224,338 & 0,585 & 0,849 & Valid \\
\hline X7 & 99,61 & 230,615 & 0,48 & 0,853 & Valid \\
\hline X8 & 99,45 & 223,835 & 0,542 & 0,85 & Valid \\
\hline X9 & 98,34 & 231,579 & 0,405 & 0,855 & Valid \\
\hline X10 & 99,23 & 228,598 & 0,467 & 0,853 & Valid \\
\hline X11 & 97,36 & 239,632 & 0,376 & 0,856 & Valid \\
\hline $\mathrm{X} 12$ & 99,23 & 228,087 & 0,431 & 0,854 & Valid \\
\hline $\mathrm{X} 13$ & 98,23 & 224,459 & 0,552 & 0,85 & Valid \\
\hline X14 & 98,25 & 247,773 & $-0,029$ & 0,867 & Not Valid \\
\hline $\mathrm{X} 15$ & 98,05 & 233,021 & 0,342 & 0,856 & Valid \\
\hline Variable & $\begin{array}{l}\text { Scale Mean if Item } \\
\text { Deleted }\end{array}$ & $\begin{array}{l}\text { Scale Variance if Item } \\
\text { Deleted }\end{array}$ & $\begin{array}{l}\text { Corrected Item- } \\
\text { Total Correlation }\end{array}$ & $\begin{array}{l}\text { Cronbach's Alpha if } \\
\text { Item Deleted }\end{array}$ & Hasil \\
\hline X16 & 97,84 & 245,16 & 0,051 & 0,864 & Not Valid \\
\hline X17 & 98,73 & 223,319 & 0,606 & 0,848 & Valid \\
\hline X18 & 97,57 & 241,228 & 0,23 & 0,859 & Not Valid \\
\hline X19 & 97,82 & 231,222 & 0,454 & 0,853 & Valid \\
\hline $\mathrm{X} 20$ & 98,77 & 230,691 & 0,392 & 0,855 & Valid \\
\hline $\mathrm{X} 21$ & 98,41 & 237,503 & 0,19 & 0,862 & Not Valid \\
\hline $\mathrm{X} 22$ & 98,64 & 228,283 & 0,638 & 0,849 & Valid \\
\hline $\mathrm{X} 23$ & 98,5 & 226,814 & 0,456 & 0,853 & Valid \\
\hline X24 & 98,18 & 249,129 & $-0,061$ & 0,867 & Not Valid \\
\hline $\mathrm{X} 25$ & 98,66 & 235,951 & 0,332 & 0,857 & Valid \\
\hline $\mathrm{X} 26$ & 98,2 & 236,911 & 0,268 & 0,858 & Not Valid \\
\hline $\mathrm{X} 27$ & 97,89 & 232,336 & 0,691 & 0,851 & Valid \\
\hline $\mathrm{X} 28$ & 98,5 & 231,884 & 0,349 & 0,856 & Valid \\
\hline X29 & 98,7 & 217,608 & 0,637 & 0,846 & Valid \\
\hline
\end{tabular}

(Source : By Author, 2019)

Table 5. Reliability Test Result

\begin{tabular}{|c|c|}
\hline \multicolumn{2}{|c|}{ Reliability Statistics } \\
\hline Cronbach's Alpha & N of Items \\
\hline 0,859 & 29 \\
\hline
\end{tabular}

(Source : By Author, 2019)

The Cronbach's Alpha coefficient value of the most influential event data on productivity is greater than 0.5 so that the instruments used in retrieving the data can be said to be reliable.

Furthermore, calculations are performed using the FI, SI, and II analyzes after carrying out the data input process of each variable to combine the results of the questionnaire that has been filled out by respondents.

Table 6. Importance Index Result (in Indonesia)

\begin{tabular}{lllll}
\hline Variable. & Value FI \% & Value SI \% & Value II \% & Conclusion \\
\hline $\mathrm{X} 1$ & 74,09 & 74,09 & 54,89 & Cukup Berpengaruh \\
$\mathrm{X} 2$ & 72,27 & 70,00 & 50,59 & Cukup Berpengaruh \\
$\mathrm{X} 3$ & 74,55 & 75,91 & 56,59 & Cukup Berpengaruh \\
\hline
\end{tabular}




\begin{tabular}{lllll}
\hline Variable. & Value FI \% & Value SI \% & Value II \% & Conclusion \\
\hline X5 & 93,18 & 90,45 & 84,29 & Sangat Berpegaruh \\
X6 & 73,64 & 74,09 & 54,56 & Cukup Berpengaruh \\
X7 & 45,00 & 51,82 & 23,32 & Kurang Berpengaruh \\
X8 & 48,18 & 55,00 & 26,50 & Kurang Berpengaruh \\
X9 & 70,45 & 67,27 & 47,40 & Cukup Berpengaruh \\
X10 & 52,73 & 50,91 & 26,84 & Kurang Berpengaruh \\
X11 & 90,00 & 85,45 & 76,91 & Berpengaruh \\
X12 & 52,73 & 51,82 & 27,32 & Kurang Berpengaruh \\
X13 & 72,73 & 70,45 & 51,24 & Cukup Berpengaruh \\
X15 & 76,36 & 74,09 & 56,58 & Cukup Berpengaruh \\
X17 & 62,73 & 69,09 & 43,34 & Cukup Berpengaruh \\
X19 & 80,91 & 75,91 & 61,42 & Berpengaruh \\
X20 & 61,82 & 61,82 & 38,21 & Kurang Berpengaruh \\
X22 & 64,55 & 67,73 & 43,71 & Cukup Berpengaruh \\
X25 & 64,09 & 68,18 & 43,70 & Cukup Berpengaruh \\
X27 & 79,55 & 80,45 & 64,00 & Berpengaruh \\
X28 & 67,27 & 60,91 & 40,98 & Cukup Berpengaruh \\
X29 & 63,18 & 64,55 & 40,78 & Cukup Berpengaruh \\
\hline (Source : By Author, 2019) & & &
\end{tabular}

From table 6, it is found that the factors that influence human resource management planning are sorted from the largest to the smallest with a measurement scale that is Very Influential, Influential, Quite Influential, and Less Influential. From these data factors can be taken that have a scale of measurement is very influential and influential. It can be seen that the variables that influence the planning of human resource management in XYZ company are: 1) Variable 5 (Incentives or bonuses for labor); 2) Variable 11 (salary suitability); 3) Variable 27 (Discipline of Management); 4) Variable 19 (The process of giving bonuses/incentives to workers from the company).

\section{Conclusions}

Based on the results of the analysis of this study, it can be concluded that:

1. The events that have the most influence on human resource management planning at XYZ company have been obtained, namely: 1) Variable 5 (Incentives or bonuses for labor); 2) Variable 11 (Suitability of Wages); 3) Variable 27 (Discipline of Management); 4) Variable 19 (The process of giving bonuses / incentives to workers from the company).

2. Event management strategies that most influence the planning of human resource management in XYZ company, namely:

a. Variable 5 (incentives or bonuses for labor) is a factor that greatly influences the planning of human resource management in XYZ company with the scale category "Very Influential" so that management will take action to collect data on workers who have high enthusiasm for working, providing bonuses or incentives that are in accordance with the results that have been made by workers, and provide bonuses or incentives only for XYZ company daily workers it is in accordance with the incentives that have been imposed by the company.

b. Variable 11 (salary suitability) is a factor that greatly affects the planning of human resource management in XYZ company with a scale category "Influential" so that from management will take action to do the data collection on receiving salaries received by workers, providing information related to wages to be received by workers before becoming XYZ company workers so that workers do not feel disappointed or discouraged when they have worked at XYZ company with the wages they receive, and provide wage increases to workers who have long worked and have loyalty to the company. This was given to improve welfare for workers.

c. Variable 27 (Discipline of Management) is a factor that greatly affects the planning of human resource management in XYZ company with a scale category "Influential" so that management will take action to 
remind management to always be disciplined and follow the applicable company procedures because management as an example for workers in the production department, making improvements in the discipline of XYZ's company management, and monitoring employees in management to see the level of discipline every day.

d. Variable 19 (The process of giving bonuses / incentives to workers from the company) is a factor that greatly influences the planning of human resource management in XYZ company with a scale category "Influence" so that management will take action to provide information to workers about the process of providing incentives to workers so not misunderstanding, the provision of incentives to workers will be done if employees can achieve the targets set by the company, and the management guarantees that the incentives will only be given to production workers who have the daily status of the company XYZ, if the targets set are exceeded.

\section{References}

Brent G. Hickson, dkk. 2014. Factors Affecting Construction Labour Productivity in Trinidad and Tobago. Kingston: The University of West Indies.

Mega Cattleya Prameswari Annissaa Islami, dkk. 2017. Analisis Pengaruh Faktor-Faktor Kerja terhadap Produktivitas Kerja pada Proyek Pembangunan Jalan Tol (Studi Kasus: Pekerjaan Pembuatan Kolom Tulangan). Surabaya: Politeknik Perkapalan Negeri Surabaya.

PMI Indonesia Chapter, 2017. PMBoK 6th Guide Edition. PMI Indonesia Chapter.

Rini, Indah Prasetya. 2018. Pengaruh Produktivitas Tenaga Kerja Terhadap Kinerja Waktu Proyek Pada Bangunan Bertingkat. Jakarta: Universitas Gunadarma.

Rino, Silfa. 2015. Pengaruh Kemampuan dan Fasilitas Kerja Terhadap Produktivitas Kerja Karyawan Bagian Produksi Pada PT. Marita Makmur Jaya Kecamatan Rupat, Kabupaten Bengkalis. Pekanbaru: Universitas Riau.

Vera Victya, dkk. 2018. Upaya Peningkatan Produktivitas Tenaga Kerja Kontraktor di Wilayah Kabupaten Paser, Kalimantan Timur. Samarinda: Universitas Lambung Mangkurat. Volume 7.

Yuniarsih, T., \& Sugiharto, M. 2016. Human Resource Management Model to Create Superior Performance. International Journal of Education, 9(1), 75-81. 